for each of the five months May to September, the absolute maximum occurring with cloudless sky and S.W. wind, on September I3, I922, namely $136.4^{\circ} \mathrm{F}$. $\left(58.0^{\circ} \mathrm{C}\right.$.), during a period of extremely high temperature throughout Tripolitania, even the coastal city of Tripoli recording as high as $\mathrm{I} I 3^{\circ} \mathrm{F}$. $\left(45^{\circ} 0^{\circ} \mathrm{C}\right.$. $)$. This appears, and is so represented by Eredia, to be the highest authentic temperature of the air ever recorded on the globe, exceeding by $2.3^{\circ} \mathrm{F}$. $\left(\mathrm{I} \cdot 3^{\circ} \mathrm{C}\right.$.) the previous "record" of $\mathrm{I} 34^{\circ} \mathrm{I}^{\circ} \mathrm{F} .\left(56 \cdot 7^{\circ} \mathrm{C}\right.$.) in Death Valley, in the south-eastern desert of California, on July 1o, I913, occurring, that is, in a similar, or rather higher latitude, close to the summer solstice, when the sun is nearly vertical. Records exceeding II $5^{\circ} \mathrm{F}$. $\left(46^{\circ} \mathrm{C}\right.$.) are stated to be common in Tripolitania, whilst other extremes from other regions, quoted for comparison, are $127.4 \mathrm{~F} .\left(53.0^{\circ} \mathrm{C}\right.$.) in the Wargla oasis of Algeria, on July I7, 1879 , and I25.9 F. $\left(52.2^{\circ}\right.$ C. $)$ at Jakobabad in N.W. India, on June I 3 , I897.

The remarkable circumstance connected with the Azizia "record" is, we think, not so much the extratropical location, since it is towards the dry. subtropical belts, where the days are longer, that the most intense summer heats occur, but that the season of its occurrence there should have been equinoctial. The mean temperature of the month of September for the seven years in question is exceedingly high, surpassing not only that of May, which is usual in northern extra-tropical latitudes, but also that of June, which is quite abnormal. This anomaly appears to be a local accentuation of the common Mediterranean characteristic of excessive summer heat lingering to a later date than in higher latitudes, where the much greater difference in the length of the day between solstice and equinox usually permits a rapid decline in temperature when August is over. Yet we know that even in England there comes every few years, with a drift northward of warm Mediterranean air, a surprising development, or resumption, of severe heat in September, with afternoon maxima at about $90^{\circ} \mathrm{F} .\left(32^{\circ} \mathrm{C}\right.$.), which sometimes causes the climatological student to wonder how the oblique equinoctial sunshine in this latitude has enough strength to raise the temperature to such levels. It should be remembered, however, that apart from the large reserve of heat stored in the air and the land- and seasurface in autumn, and its easy transport by air currents from heated southern regions, enabling a smaller amount of solar radiation to raise the temperature to $80^{\circ}$ or $90^{\circ} \mathrm{F}$. $\left(27^{\circ}\right.$ to $32^{\circ} \mathrm{C}$.) than is necessary early in the summer, the very fact that the equinoctial sunshine is feebler, implying a smaller amount of surface heating, involves in turn, in conjunction with the relatively warm upper air in the autumn, a shallower vertical temperature gradient, and lessened tendency to convection, than at the high solstice. The result of this is that the heat is kept more to the surface, and that September " heat-waves," when they do occur, are liable to be scarcely less severe than those of July and August, and rather more so than those of May and June, when the fierce insolation, coupled with the yet cold upper air in early summer, favours instability with removal of the warm air from the surface and a checking of the afternoon maxima.

The circumstances attending the highest temperature which has yet been "caught" by our observing stations, may be summarised as follows: It occurred during a period of cloudless sky with light winds from the heated regions of the Sahara, in the middle of a semi-desert plain well inland from the sea, in a latitude $\left(32 \frac{1}{2}^{\circ} \mathrm{N}\right.$.) which, astronomically at least, belongs to the temperate zone, at a date (Sept. 13) only ten days on the summer side of the autumn equinox, when the sun is nearly half-way between its extreme solstitial position. The time of year is a prominent illustration of the general climatological principle that the seasonal extremes of temperature, even in continental regions, tend to lag well behind the corresponding extremes in the intensity and duration of sunlight. The latitude, too, illustrates the somewhat paradoxical principle that in general it is not the equatorial or hottest climates, that is, those with the highest mean temperatures, that furnish the occasional extremes of heat, say above $120^{\circ} \mathrm{F}$. (circ. $50^{\circ} \mathrm{C}$.), but the cooler and drier climates, near the confines of the tropics, which are intensely hot during the summer months.

L. C. W. Bonacina.

\title{
Past and Passing Peoples of Polynesia.
}

SOME important studies of two Polynesian peoples are published by the Bayard Dominick Expedition in the Memoirs of the Bishop Museum at Honolulu. ${ }^{1}$ In vol. ix. Mr. H. D. Skinner gives a comprehensive account of the almost extinct Morioris of Chatham Islands. Of these only two living representatives were found in a population of foreigners, most of whom were Maoris. One other was living in New Zealand. In vol. viii. Mr. R. Linton discusses the material culture of the Marquesans, and in vol. ix. Mr. L. D. Sullivan their somatology. These are also a dying and diseased race and Mr. Sullivan doubts whether there is a wholly sound physical specimen alive, while Mr. Linton considers that their language and portions of their culture may be preserved for several generations by their numerous half-Chinese or half-European descendants, who are more resistant to disease than the pure-blooded natives.

Mr. Linton's account of the Marquesans is restricted

1 "'The Material Culture of the Marquesas Islands." By Ralph Linton Memoirs of the Bernice P. Bishop Museum, vol. viii. No. 5 (Bayard Dominick Expedition. Publication No, 5.) Honolulu, Hawaii, r923.

"The Morioris of Chatham Islands." By H. D. Skinner. Memoirs of the Bernice P. Bishop Museum, vol. ix. No. x. (Bayard Dominick Expedition. Publication No. 4.) Honolulu, Hawaii, 1923

"Marguesan Somatology with Comparative Notes on Samoa and Tonga.' By Louis R. Sullivan. Memoirs of the Bernice P. Bishop Museum, vol. ix No. 2. (Bayard Dominick Expedition. Publication No. 6.) Honolulu, Hawaii, x923.

$$
\text { NO. } 2860 \text {, VOL. I I } 4]
$$

to their material culture, and other features having been dealt with elsewhere, only a short summary is given of social organisation and religion. But houses, canoes, stone artifacts, weapons and implements, clothing and ornament are described in detail and illustrated by forty-four full-page plates and eleven figures in the text. The few local differences in the islands are set out in a comparative table, which is repeated in greater detail to exhibit the relations of the Marquesan material culture to that of other Polynesian groups. Samoa and Tonga are found to have a closer cultural agreement than any other two localities. The Marquesas and New Zealand are almost equally close. The Society Island culture comes between the Samoan-Tongan and the MaoriMarquesan. Hawaiian culture resembles the MaoriMarquesan on the material side, but is more nearly related on the non-material side to the Society Islands and Western Polynesia.

The author gives the following hypothesis of the historic distribution of races and culture in the Pacific. The first arrivals in Central and South-east Polynesia were Negroid and Melanesian rather than Polynesian in culture. They settled in Tonga, Samoa, the Cook, Society, Austral, and Tuamotu groups. They did not reach the farther islands and came from Melanesia, probably Fiji. The next comers 
were of the Caucasic race and came by way of Micronesia from Indonesia to Samoa. They produced a hybrid race and the south-east Polynesian type of culture. A fairly pure group of this Caucasic race reached the Marquesas and, mixed with the Negroids, arrived in Easter Island. Another group passed through Melanesia and modified the culture of the Eastern Melanesian Islands. The last comers were the Indonesians, who entered by way of Micronesia and thence passed to Tonga and, mixed with earlier people, to Hawaii. In Samoa they were resisted for a time by the earlier population, which in Niue survived into historic times. From Western Polynesia the Indonesians colonised New Zealand, spread over South-east Polynesia and reached the Marquesas. Later movements from the west have modified the culture and rendered it extremely complex.

In Mr. Sullivan's study of Marquesan, Samoan, and Tongan somatology, the distinctions of race are elaborated in a series of anthropometric tables based upon the examination of 84 adult men and 74 adult women of the Marquesan islands. These were compared with his similar studies of Samoans and Tongans in other papers. His estimate of the physical condition of the people has been already quoted. The measurements show the Marquesans to be " tall, with long, wide head, a high, wide face, and a high, wide nose. All of the dimensions of the head and body are large, indicating their massive size. They are on the verge of brachycephaly. But one cannot be sure that the heads are wholly undeformed."

According to Mr. Sullivan the "Polynesians" of the Marquesas, Samoa, and Tonga are a mixed people. $\mathrm{He}$ finds in them three racial types. In addition to the Polynesian population there is a second type resembling the Indonesian peoples of Malaysia, and a third extremely short-headed element. He has dealt mainly with the Polynesian and Indonesian types. The former are taller, with longer heads, higher faces, narrower noses, perhaps straighter hair, more beard and body hair, and lighter skin than the Indonesians. They appear thus to be the Caucasic people of Mr. Linton's hypothesis.

Mr. H. D. Skinner's monograph on the Morioris is exhaustive as regards the material culture of the people and their relation to the Maoris and other Pacific islanders. It is prefaced by an admirable summary account of the bodily and mental characteristics of the Morioris, their language, social organisation, and religion. This is derived partly from the very scattered accounts of earlier writers, but has been considerably extended by Mr. Skinner's own investigations in the Chatham Islands. As in the Marquesan papers, the illustrations are an important feature. The paper before us contains thirtysix figures in the text, and thirty-five full-page plates.

With regard to the origin of the Moriori, Mr. Skinner gives a summary of their own traditions as recorded by Shand and the Maori version of Whatatoro, which was accepted as accurate by Mr. Percy Smith and Mr. Elsdon Best. The Moriori account seems to show at least two principal immigrations from unknown lands, the last of which took place, if the genealogies may be relied upon, about thirty generations ago, or about A.D. II75. According to the Maori account they were a portion of the original inhabitants of New Zealand, called Maruiwi, who had been driven by a storm while fishing from a great land south-west of New Zealand. Mr. Skinner point out the inherent improbabilities of this story: the presence of women in a fishing party, the food required for a thousand-mile journey, and the impossibility of people in the cultural stage attributed to the Maruiwi possessing ocean-going canoes. The Maruiwi, moreover, were the physical antitheses of the Moriori. They were tall, thin, dark-skinned, with flat noses and straight hair, whilst the Moriori are short and bulky, brown-skinned, with prominent noses, and hair often waved and sometimes frizzy. The Maruiwi lived wholly on forest produce, and knew nothing of fine weaving, but the Morioris had a traditional knowledge of cultivated plants, and made fine matting. Not one of the Moriori weapons described by Mr. Skinner is mentioned in the account of the Maruiwi.

Mr. Skinner's final remarks are important. The craniology of the Moriori shows close relationship with the Maori, and some social features are identical. The language is divergent, but $\mathrm{Mr}$. Skinner suggests a likeness to the Kaitahu of South New Zealand. The evidence of material culture is decisively in favour of a Maori origin, though some evidence appears of a likeness with Easter Island and Melanesia in the conception of human and animal forms in art, and in some hooks and adzes.

Taken as a whole these three studies considerably increase our knowledge of the Polynesians. But their conclusions have yet to be compared with the evidence of language, sociology, and religion.

Sidney H. Ray.

\section{Ancient and Modern Arithmetic.}

THE special object of the papers referred to below ${ }^{1}$ appears to be to establish one main thesis, namely, that there was no such thing as arithmetic in our modern sense before the sixteenth century. To quote the author's words: "Modern arithmetic, which is a peculiarly Western invention, is yet barely 400 years old. Prior to I 500, and during some 3500 years of unbroken mathematical continuity and evolution, the science and art of calculation differed absolutely from anything in vogue with us."

The sole direct argument by which the author supports this thesis is the occurrence, in two particular treatises on arithmetic which he quotes, of a method of multiplying two digits to which he applies the general term "calculation by deficients." The anonymous English author of "An introduction for to lerne to recken with the pen, or with the counter,

1 "The Transition from Ancient to Modern Arithmetic, I. II." (reprinted from The Teachers' Magazine, Montreal, Dec. 1923 and April 1924); "Calculation by Deficients (a remarkable aspect of the Evolution of Arithmetic)," a paper read before the American Oriental Society, April 23 r 924 ; by the Rev. C. A. Brodie Brockwell. accordying to the trewe cast of algorism, in hole numbers or in broken, etc," written in 1546 , multiplies 7 by 5 , and for this purpose substitutes (10 - 3) for 7 , arriving at the result by a process which is equivalent to $7 \times 5=(10-3) 5=50-I_{5}=35$. The Frenchman Oronce Fine (not "Finé"), whose work was first. published during the years I 530-32 (not I525), uses. an even more roundabout process equivalent to $7 \times 5=($ Io -3$)($ Io -5$)=15+(7-5)$ Io $[$ or $(5-3)$ Io $]=$ $15+20=35$

Now this "complementary" method of multiplication (as it has been called) is a familiar item in most histories of mathematics: there is nothing new in Prof. Brockwell's discovery. He says, indeed, that the anonymous English treatise " appears to have been entirely overlooked by all the more recent writers on the history of mathematics both in Europe and America "; but, if he had referred to David Eugene Smith's “ Rara Arithmetica” (I908), he would have found (p. 244) a notice of this anonymous work and of the later edition of it published in 